HortSCIENCE 27(2):105-106. 1992.

\title{
Carrot Yield when Grown under Three Soil Water Concentrations
}

\author{
James M. White \\ Institute of Food and Agricultural Sciences, Central Florida Research \\ and Education Center, University of Florida, 2700 East Celery Avenue, \\ Sanford, FL 32771-9608
}

Additional index words. Daucus carota, organic soils, water regime, water requirement

Abstract. 'Orlando Gold' carrots (Daucus carota L.) were grown in plastic containers filled with an organic soil and placed in a greenhouse in the fall and spring. Three (high, medium, and low) soil water concentrations of $48 \%$ (low), $54 \%$ (medium), and $60 \%$ (high) were used. The number of marketable roots was higher following the fall than the spring planting. The high and low soil water concentrations significantly reduced the number of marketable roots over the medium concentration, but only the high concentration reduced the total marketable weight in both plantings. Application of the high soil water concentration reduced root length but not width measured at 2.5 cm below the crown relative to the medium and low soil water concentrations. Carrots will produce marketable roots when grown in a wide range of soil water concentrations, but the high concentration reduced yield more than the low concentration.

Horticultural crops differ in their tolerance to high or excess soil water concentration (Goins et al., 1966; Sri Agung and Blair, 1989; Williamson and Gray, 1973) and in the effect of soil water concentration on marketable yields. Factors such as the physical properties of the soil (Cook et al., 1963; Sri Agung and Blair, 1989) and temperature (Barnes, 1936; Banga et al., 1955) affect the tolerance of crops to high soil water concentration. Hill and Sumner (1967) found that in sand soils, where most pore volume consisted primarily of large pores, the effect of compaction was more pronounced at high

Received for publication 6 June 1991. Accepted for publication 10 Sept. 1991. Florida Agricultural Experiment Station Journal series no. R-01663. The cost of publishing this paper was defrayed in part by the payment of page charges. Under postal regulations, this paper therefore must be hereby marked advertisement solely to indicate this fact. than low soil water concentrations. White (1978) concluded that certain tillage practices used in carrot production on organic soils (histosols), such as a Lauderhill muck, contributed to soil compaction, more culls, and, therefore, lower marketable yields. White and Strandberg (1979) concluded that when young carrot roots were exposed to watersaturated soil roots were shorter and had more discolored tips and forked roots than under lower water concentrations. Henkel (1970) and Millette (1983) found that carrot yields and root length were more influenced by water table and soil water content during the vegetative period than during root enlargement.

This study was conducted to determine the effect of three soil water concentrations on growth of carrots grown on an organic soil.

Lauderhill muck soil from a field in which carrots had been grown in Zellwood, Fla., was steam sterilized and placed into 19-liter plastic containers $(28.6 \mathrm{~cm}$ diameter, 35.6 
The relationship between three soil water concentrations as measured by a soil moisture meter probe and percent soil moisture in Lauderhill muck soil and the aveiage soil water meter readings during the fall and spring plantings of carrots.

\begin{tabular}{|c|c|c|c|c|}
\hline \multirow{2}{*}{$\begin{array}{l}\text { Soil water } \\
\text { concn }\end{array}$} & \multirow{2}{*}{$\begin{array}{l}\text { Target } \\
\text { probe } \\
\text { reading }\end{array}$} & \multirow{2}{*}{$\begin{array}{c}\text { Soil } \\
\text { water } \\
(\%)\end{array}$} & \multicolumn{2}{|c|}{ Average reading } \\
\hline & & & Fall & Spring \\
\hline $\begin{array}{l}\text { High } \\
\text { Medium } \\
\text { Low }\end{array}$ & $\begin{array}{l}9.8 \\
7.6 \\
2.6\end{array}$ & $\begin{array}{l}60.5 \mathrm{a}^{\mathrm{y}} \\
54.6 \mathrm{~b}^{2} \\
48.2 \mathrm{c}\end{array}$ & $\begin{array}{l}8.8 \mathrm{a} \\
7.3 \mathrm{~b} \\
2.1 \mathrm{c}\end{array}$ & $\begin{array}{l}9.1 \mathrm{a} \\
7.7 \mathrm{~b} \\
3.8 \mathrm{c}\end{array}$ \\
\hline
\end{tabular}

${ }^{2}$ Soil water kg \% dry weight.

'Mean separation in columns by Duncan's multiple range test, $\mathrm{P}=0.05$.

Table 2. Results of three soil water concentrations during the growing of 'Orlando Gold' carrots on marketable number, weight, and size of roots.

\begin{tabular}{|c|c|c|c|c|c|c|}
\hline \multirow[b]{2}{*}{$\begin{array}{l}\text { Soil water } \\
\text { concn }\end{array}$} & \multirow{2}{*}{$\begin{array}{l}\text { Total roots/ } \\
\text { container } \\
\text { (no.) }\end{array}$} & \multicolumn{5}{|c|}{ Marketable roots/container } \\
\hline & & No. & $\begin{array}{c}\text { Total } \\
(\mathrm{kg})\end{array}$ & $\begin{array}{c}\text { Root wt } \\
(\mathrm{kg})\end{array}$ & $\begin{array}{c}\text { Length } \\
(\mathrm{cm})\end{array}$ & $\begin{array}{l}\text { Diam } \\
(\mathrm{cm})\end{array}$ \\
\hline & \multicolumn{6}{|c|}{ Fall study } \\
\hline High & $23.2 b^{2}$ & $14.6 \mathrm{~b}$ & $7.3 \mathrm{~b}$ & $0.50 \mathrm{c}$ & $15.8 \mathrm{~b}$ & $2.3 \mathrm{a}$ \\
\hline Med & $29.4 \mathrm{a}$ & $20.2 \mathrm{a}$ & $11.9 \mathrm{a}$ & $0.59 \mathrm{a}$ & $17.9 \mathrm{a}$ & $2.4 \mathrm{a}$ \\
\hline Low & $21.0 \mathrm{~b}$ & $13.8 \mathrm{~b}$ & $7.9 \mathrm{ab}$ & $0.57 \mathrm{~b}$ & $17.7 \mathrm{a}$ & $2.4 \mathrm{a}$ \\
\hline \multicolumn{7}{|c|}{ Spring study } \\
\hline High & $24.0 \mathrm{a}$ & $9.4 \mathrm{c}$ & $6.4 \mathrm{c}$ & $0.68 \mathrm{c}$ & $20.1 \mathrm{~b}$ & $2.4 \mathrm{~b}$ \\
\hline Medium & $24.8 \mathrm{a}$ & $17.4 \mathrm{a}$ & $14.1 \mathrm{a}$ & $0.81 \mathrm{~b}$ & $22.2 \mathrm{a}$ & $2.7 \mathrm{ab}$ \\
\hline LOW & $18.0 \mathrm{~b}$ & $12.8 \mathrm{~b}$ & $11.8 \mathrm{~b}$ & $0.92 \mathrm{a}$ & $23.2 \mathrm{a}$ & $3.4 \mathrm{a}$ \\
\hline
\end{tabular}

'Mean separation in columns by Duncan's multiple range test, $\mathrm{P}=0.05$.

$\mathrm{cm}$ high). Four $1.3-\mathrm{cm}$ holes had been drilled into the lower side of each container for drainage. Seeds of 'Orlando Gold' carrot were hand planted into three evenly spaced furrows $\approx 2 \mathrm{~cm}$ deep and covered using slight hand pressure. The containers were then placed in a glass greenhouse without supplemental light or shade. Temperatures were kept between 5 and 30C.

Carrots were grown in a fall and spring study using three soil water concentrations: low, medium, and high. Soil water concentrations were based on a soil moisture meter probe with a reading range for the low soil water concentration from 2.5 to $2.6(48.2 \%$ soil water concentration), for the medium from 7.6 to 8.2 (54.6\% soil water concentration), and for the high from 9.8 to $9.9(60.5 \%$ soil water concentration) on a scale of 0 to 10 by weight. The target probe readings were established by sampling a series of dry, moist, and wet soils, taking the probe reading, and then determining the percent soil water in each by drying and weighing. The soil water concentration readings were taken 5 days.week ${ }^{-1}$ from each container at four locations at a depth of $12 \mathrm{~cm}$ to determine the average readings. Water was added by pouring from a measuring beaker to maintain the soil water concentration within the established range.

In each planting, the three soil water concentration treatments were replicated five times occupying 15 containers and were placed in the greenhouse in a random-block design. For the fall study, seed was planted 18 Oct. and roots were harvested 12 Feb. (117 days). For the spring study, seed was planted 24 Feb. and roots were harvested 13 June (109 days). In the spring study, carrots were hand thinned on 24 Mar. to one plant per $2.5 \mathrm{~cm}$ of row length. Data were collected on the total and marketable number of roots, marketable root weight, length, and diameter at $2 \mathrm{~cm}$ below the crown. Total number of roots included those not marketable, i.e., carrots $<1.9 \mathrm{~cm}$ in diameter or $>3.8 \mathrm{~cm}$, those $<12.7 \mathrm{~cm}$ long, or those with cracks, splits, and forks. Small-sized roots accounted for the majority of the unmarketable carrots.

The average soil water concentration as measured by a soil moisture meter probe was significantly different for each level (high, medium, and low) during the fall and spring studies (Table 1). Reading averages were slightly lower in the fall than during the spring study.

Over all soil water concentrations, there were more marketable roots (48.6 vs. 39.6), was less total weight ( 27.1 vs. $32.3 \mathrm{~kg}$ ), less average weight per root (0.56 vs. $0.82 \mathrm{~kg})$, shorter root length $(17.2$ vs. $22.0 \mathrm{~cm})$, and smaller root diameter $(2.4$ vs. $2.8 \mathrm{~cm})$ in the fall than in the spring study.

In the fall study, the marketable number and average root weight were significantly higher for carrots grown in the medium than in the high or low soil water concentration (Table 2). The highest total marketable carrot weight was also produced with the medium soil water concentration. Although total carrot marketable weight produced with the medium soil water concentration treatment was not significantly different from the low treatment, it was significantly higher than the high treatment. Carrots produced with the medium or low soil water concentration were significantly longer than those produced with the high concentration. Marketable carrot root diameter measured $2.5 \mathrm{~cm}$ below the crown was not affected by any of the soil water concentration treatments. Unmarketable roots generally were too short and/ or had a diameter $\mathrm{cl} .9 \mathrm{~cm}$.

In the spring study, significantly more marketable carrot roots and more total weight were produced with the medium soil water concentration than with the low concentration; the lowest amount was produced with the high water concentration. The average root weight was highest with the low soil water concentration, and lowest with the high concentration. The shortest and thinnest marketable carrots were produced with the high soil water concentration. Small carrots accounted for most unmarketable roots in the spring and fall studies.

The large water holding capacity of organic soil was indicated by the narrow range of percent soil water concentration found when dry weights were determined on soil with each of the water regimes (48\% to $60 \%$ ). Within this narrow range, plants at $48 \%$ moisture wilted between waterings as they matured. These results suggest that carrots will produce marketable roots when grown in a wide range of soil water concentrations and that high soil water concentration reduced yield, average root weight, and length more than low soil water concentration within the soil water concentrations studied.

\section{Literature Cited}

Banga, O., J.W. DeBruyn, and L. Smeets. 1955. Selection of carrots for carotene content. II. Subnormal content at low temperature. Euphytica 4:183-188.

Barnes, W.C. 1936. Effects of some environmental factors on growth and color of carrots. Memoir. Cornell Agr. Expt. Sta. 186:1-36.

Cook, R.L., A.E. Erickson, and P.R. Krone. 1963. Soil factors affecting constant water level subirrigation. J. Amer. Soc. Hort. Sci. 62:491495

Goins, T., J. Lunin, and W.L. Worley. 1966. Water table effects on growth of tomatoes, snap beans, and sweet corn. Trans. Amer. Soc. Agr. Eng. 9:530-533.

Henkel, A. 1970. Investigations on the use of irrigation for late carrots. Hort. Abstr. 40:8634.

Hill, J.N.S. and M.E. Sumner. 1967. Effect of bulk density on moisture characteristics of soils. Soil Sci. 103:234-238.

Millette, J.A. 1983. Effect of water table depths on the growth of carrots and onions on an organic soil. Can. Plant Sci. 83:739-746.

Sri Agung, I.G.A.M. and G.J. Blair. 1989. Effects of soil bulk density and water regime on carrot yield harvested at different growth stages. J. Hort. Sci. 64:17-25.

Williamson, R.E. and T.N. Gray. 1973. Effect of water table depth on yield of cabbage, squash, and tendergreen. J. Amer. Soc. Hort. Sci. 98:207-209.

White, J.M. 1978. Soil preparation effects on compaction, carrot yield, and root characteristics in organic soil. J. Amer. Soc. Hort. Sci. 103:433-435.

White, J.M. and J.O. Strandberg. 1979. Physical factors affecting carrot root growth: water saturation of soil. J. Amer. Soc. Hort. Sci. 104:414416. 